\title{
Aplikasi Media Pembelajaran Operasi Hitung Perkalian dan Pembagian Berbasis Android
}

\author{
Mairissa Anggraini ${ }^{\star 1}$, Gita Indah Marthasari ${ }^{2}$, Lailatul Husniah ${ }^{3}$ \\ ${ }_{1,2,3}^{2}$ Teknik Informatika/Universitas Muhammadiyah Malang \\ mairisanggraini@gmail.com ${ }^{* 1}$, gita.voyager@gmail.com², lailatulhusniah @gmail.com³
}

\begin{abstract}
Abstrak
Semakin banyaknya teknologi yang berkembang pada saat ini menjadi suatu hal yang penting karena dapat membantu dalam mengerjakan kegiatan sehari-hari seperti pada aplikasi yang dibangun ini bertujuan untuk meningkatkan minat belajar para siswa. Berdasarkan analisis yang dilakukan kepada guru pengajar dan siswa sekolah dasar kelas 3, kebanyakan guru pengajar masih menggunakan media gambar, biji-bijian dan lain sebagainya untuk mempraktek kan perhitungan perkalian dan pembagian. Matematika memang dianggap pelajaran yang sulit bagi kalangan siswa, maka dari itu dibuat aplikasi berbasis android untuk membuat siswa mudah memahami pelajaran sesuai dengan kurikulum disekolah. Sehingga siswa dapat menjadi aktif dalam belajar agar mereka tidak jenuh dengan pelajaran yang monoton yang tentunya akan menjadi pengaruh terhadap pencapaian hasil pembelajaran yang lebih optimal. Berdasarkan hasil evaluasi aplikasi yang telah dibuat dilakukan pengujiaan tes kegunaan dengan menggunakan metode system usability scale (SUS) yang dapat memberikan hasil berdasarkan perolehan sampel dengan cara kuisioner. Perhitungan system usability scale (SUS) didapat dengan cara mencari nilai rata-rata dari seluruh responden. Hal ini yang menjadi informasi layak atau tidaknya aplikasi yang dibangun. Nilai yang didapat untuk aplikasi ini yaitu 75, 4 sehingga dapat dikatakan bahwa aplikasi ini telah berjalan dengan baik. Selain itu juga dilakukan kuisioner dengan jumlah responden sebanyak 34 siswa, dari hasil kuisioner tersebut didapatkan bahwa aplikasi ini dapat membantu mereka untuk belajar perkalian dan pembagian.
\end{abstract}

Kata Kunci: Matematika, Media Pembelajaran, Android

Abstract
The growing number of technology that developed at this time becomes an important thing because it can assist in daily activities such as this built application to increase students learning interest. Based on the analysis that has done to teachers and students of grade 3 primary school, a lot a teacher still use some medias of teach, such as picture of thing, grains and etc to practice the multiplication and division. Mathematics is difficult lesson for some students, therefore made an android based application to make students easy to understand the lesson according to the school curriculum. In order to they are not saturated with monotonous lessons which will certainly be an influence on the results of learning to be more optimal. Based on the evaluation results of application which has built, there was usability testing to evaluate that using system usability scale (SUS) method which can give results based on value by way of questionnaire. The calculation of system usability scale (SUS) is obtained by finding the average of all respondents. This result of it to be information worthy or not the application. The value obtained for this application is 75,4 so it can be said the application has been running well. In addition, a questionnaire was also conducted with the number of respondents as many as 34 students, from the results of the questionnaire obtained this application can help them to learn multiplication and split.

Keywords: Mathematics, Media Learning, Android

\section{Pendahuluan}

Matematika merupakan pelajaran yang dianggap rumit oleh siswa karena ada banyak cara dalam menyelesaikan berbagai permasalahan sehari-hari melalui perhitungan [1]. Saat belajar, siswa memperhatikan guru dalam menyelesaikan suatu persoalan matematika, sehingga membuat siswa harus memahami bagaimana cara menjawab soal latihan dan mengaplikasikan hal tersebut dalam kehidupan sehari-hari [2]. 
Strategi pembelajaran oleh pengajar saat ini masih membuat siswa jenuh dalam belajar. Untuk dapat meningkatkan motivasi belajar, dibutuhkan model pembelajaran yang dapat membuat siswa berpikir kritis, memiliki keterampilan sosial, serta meningkatkan hasil belajar siswa untuk mendapatkan pencapaian pembelajaran lebih optimal [3]. Oleh karena matematika merupakan mata pelajaran yang dianggap sulit oleh anak-anak, maka diperlukan teknik pembelajaran yang menarik dan diminati agar tidak beranggapan bahwa matematika pelajaran yang sulit, membosankan dan menakutkan.

Operasi perhitungan perkalian dan pembagian merupakan salah satu kurikulum dari materi mata pelajaran matematika yang dipelajari oleh siswa kelas 3 Sekolah Dasar (SD). Karena ada banyak cara untuk menyelesaikan masalah operasi hitung perkalian dan pembagian, sehingga membuat siswa kebingungan dalam menemukan jawaban yang tepat dan benar. Perlu adanya media pembelajaran untuk melakukan pendekatan agar siswa dapat lebih memahami konsep, menarik minat para siswa untuk mempelajari materi, dan tentu membuat siswa tidak merasa bosan untuk belajar perhitungan matematika [4]. Dengan menggunakan media gambar yang menarik, suara, animasi, dan beberapa latihan soal sehingga dapat membuat mereka lebih tertarik belajar apabila dibandingkan dengan menggunakan media buku pelajaran dan papan tulis [5]. Adapun penelitian tentang media pembelajaran sebelumnya tentang media pembelajaran interaktif matematika untuk kelas VII yang dimana tujuan aplikasi media pembelajaran ini adalah untuk membuat siswa menyukai pelajaran matematika yaitu dengan cara mengkoordinir minat siswa antara pola keseharian mereka dimana banyak siswa yang sangat senang dengan aktifitas belajar sambil bermain. Oleh karena itu, maka dibuatlah aplikasi media pembelajaran matematika ini guna untuk menarik minat siswa untuk belajar [6].

Pada penelitian [7] merancang aplikasi media pembelajaran interaktif Sakawira Kartika yang digunakan untuk mempelajari pramuka Saka Kartika melalui smartphone. Media pembelajaran ini memberikan sebuah kuis dengan format permainan sederhana yang berisi tentang praktek-praktek mengenai materi yang diajarkan seperti pembuatan simpul sehingga diharapkan dapat membuat pelajar lebih memahami Saka Wira Kartika dengan mudah. Hal seperti inilah membuat saya tertarik untuk membuat suatu aplikasi media pembelajaran matematika tentang perkalian dan pembagian dengan memanfaatkan mobile dalam membuat aplikasi media pembelajaran. Selain itu juga menggunakan adobe flash untuk membuat ilustrasi yang berupa tutorial tentang cara memecahkan masalah perkalian dan pembagian berbasis android yang dapat berguna untuk menarik minat belajar untuk siswa kelas 3 SD.

Berdasarkan wawancara yang dilakukan dengan ibu wali kelas 3 SDN Dinoyo 3 Malang, diperoleh informasi bahwa masih terdapat siswa yang kurang antusias dalam mengikuti pelajaran matematika tentang perkalian dan pembagian. Guru menggunakan media gambar yang dijelaskan pada papan tulis dan menggunakan biji-bijian untuk menjelaskan materi pelajaran tentang perkalian dan pembagian. Beliau juga menambahkan bahwa dengan adanya media gambar tentu akan meningkatkan minat belajar mereka dan pasti sangat membantu apabila dibuat dengan lebih menarik apalagi aplikasi di handphone karena anak-anak dapat sambil bermain dan mereka juga dengan mudah menggunakannya karena bisa diakses kapanpun dan dimanapun sehingga akan meningkatkan minat belajar ketika berada diluar sekolah.

Berdasarkan hasil angket analisis kebutuhan terhadap siswa kelas 3 di SDN Dinoyo 3 Malang pada tanggal 31 Maret 2017 diperoleh data bahwa dari 39 siswa, hanya 27 siswa yang menganggap bahwa pelajaran tentang perkalian dan pembagian mudah dipahami. Sebanyak 31 siswa berpendapat dengan adanya media pembelajaran akan membuat mereka senang dalam belajar ketika menggunakan handphone diluar sekolah dan 36 siswa akan sangat tertarik jika materi perkalian dan pembagian disajikan kedalam bentuk animasi gambar, video, dan suara.

\section{Metodologi}

Pada bagian ini akan dijelaskan tentang teori yang digunakan untuk penulisan dan rancangan aplikasi media pembelajaran ini.

\subsection{Multimedia Develpoment Life Cycle (MDLC)}

Metodologi penelitian merupakan langkah untuk meneliti suatu objek. Tahapan ini dimulai dengan pengonsepan hingga sampai pada tahap distribusi, yang nantinya akan menjadi acuan penelitian agar tidak menyimpang dari tujuan penelitian. Metode yang akan digunakan dalam pengembangan aplikasi media pembelajaran ini adalah Multimedia Development Life Cycle yang terdiri dari enam tahapan yaitu [8]:

REPOSITOR, Vol. 2, No. 2, Februari 2020: 225-238 


\subsubsection{Pengonsepan (Concept)}

Pada tahap ini dilakukan identifikasi masalah dengan melakukan studi literatur yang bisa didapatkan dengan mempelajari dari buku, jurnal, artikel, dan karya tulis ilmiah. Mempelajari literatur tampilan aplikasi mengenai design yang bersifat user friendly sehingga dapat digunakan dengan mudah oleh user. Kemudian melakukan wawancara kepada ibu guru wali kelas 3 SDN Dinoyo 3 Malang untuk menanyakan proses belajar mengajar dikelas terutama tentang pelajaran perkalian dan pembagian. Setelah itu melakukan observasi untuk mendapatkan analisa kebutuhan dari sistem yang akan dibuat. Pada tahapan ini adik-adik kelas 3 diminta mengisi kuisioner dengan beberapa kriteria pertanyaan dan kemudian mereka akan menjawab ya atau tidak.

\subsubsection{Perancangan (Design)}

Merupakan perancangan desain dari aplikasi yang akan dibuat yaitu melakukan penyesuaian dengan tools yang digunakan. Dalam tahap ini digunakan storyboard, user interface, dan lain sebagainya untuk representasi desain aplikasi yang dibuat. Adapun storyboard untuk animasi konsep perkalian dan pembagian seperti pada Gambar 1 dna Gambar 2.

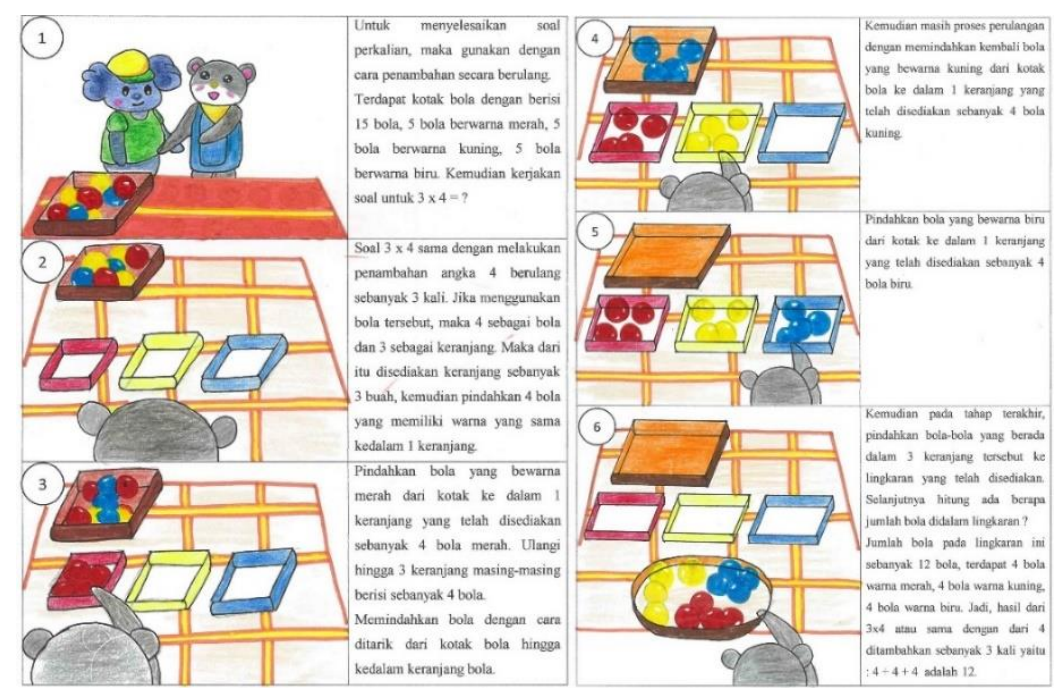

Gambar 1. Storyboard Perkalian

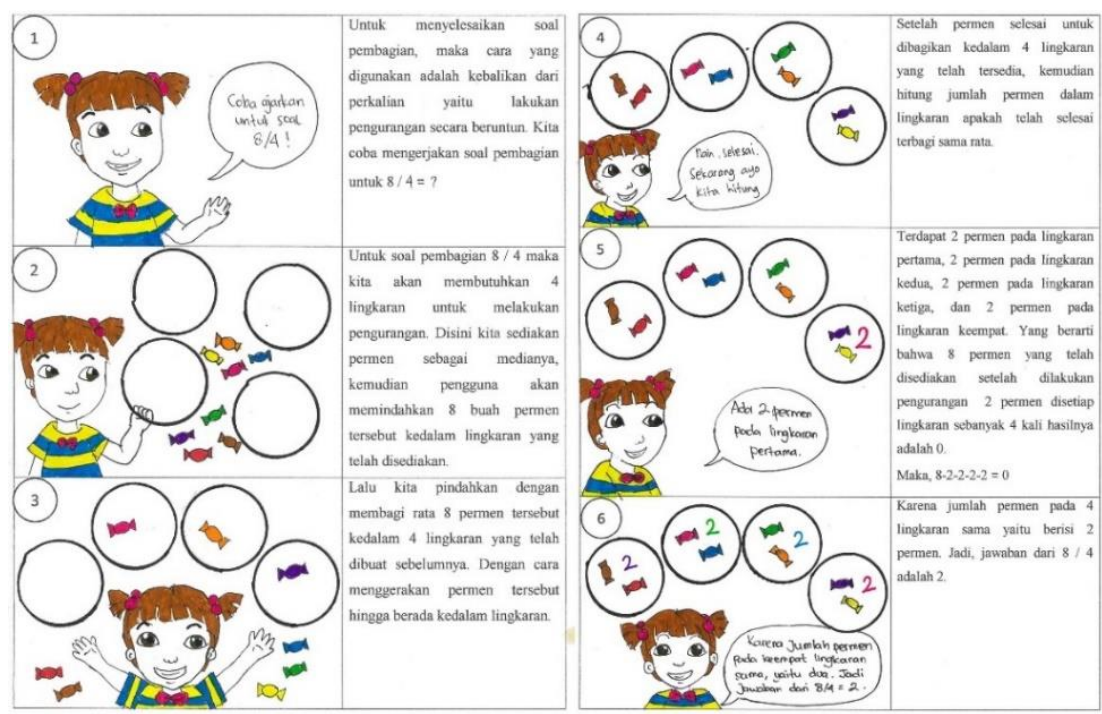

Gambar 2. Storyboard Pembagian

Adapun user interface pada Tabel 1, Tabel 2, Tabel 3, dan Tabel 4 aplikasi media pembelajaran ini, yaitu: 
Tabel 1. Rancangan Tampilan Awal

$\begin{array}{ll}\text { Tampilan Sistem } & \begin{array}{l}\text { MATEMATIKA } \\ \text { Perkalandan PEMBagian }\end{array} \\ \text { Keterangan } & \begin{array}{l}\text { merupakan halaman utama terdapat pilihan button materi, } \\ \text { belajar, latihan, bantuan untuk memberikan penjelasan } \\ \text { menggunakan media pembelajaran ini, dan close untuk keluar } \\ \text { dari aplikasi. }\end{array}\end{array}$

Tabel 2. Rancangan Tampilan Menu Belajar

Tampilan Sistem

Pada halaman menu belajar terdapat pilihan konsep yang dapat dipilih oleh user sesuai apa yang ingin mereka Keterangan pelajari. Tombol menu untuk kembali pada menu utama.

Tabel 3. Rancangan Halaman Menu Latihan

\begin{tabular}{cl}
\hline Tampilan Sistem & $\begin{array}{l}\text { Pada halaman menu latihan ini juga terdapat pilihan latihan } \\
\text { Soal yang dapat dipilih oleh user sesuai apa yang ingin } \\
\text { Kereka kerjakan untuk bermacam latihan soal. Tombol } \\
\text { menu untuk kembali pada menu utama. }\end{array}$ \\
\hline
\end{tabular}

Tabel 4. Rancangan Halaman Bantuan

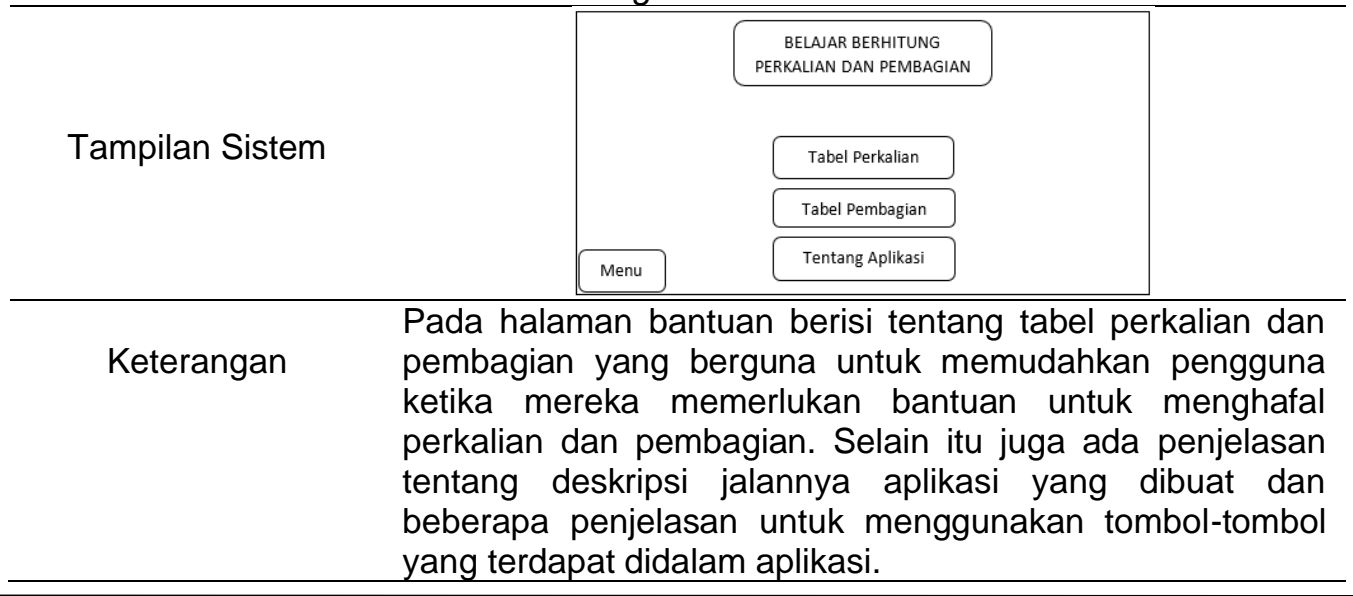

REPOSITOR, Vol. 2, No. 2, Februari 2020: 225-238 


\subsubsection{Pengumpulan Material (Collecting Material)}

Dalam tahapan ini akan dikumpulkan materi atau bahan yang akan dibutuhkan meliputi gambar, animasi, audio, dan yang dibutuhkan lainnya sesuai dengan rancangan. Selama tahap ini semua data, gambar, audio, dan video untuk aplikasi yang diunduh dari beberapa sumber yang telah dicantumkan dikumpulkan kedalam format digital yang sesuai. Selain itu adapun konten materi dan belajar diambil dari buku sekolah Cerdas Berhitung Matematika Untuk SD/MI kelas 3 terbitan Pusat Perbukuan Departemen Pendidikan Nasional (Depdiknas) [9].

Pada penelitian ini file movie yang merupakan animasi akan dihasilkan menggunakan flash. Movie yang dihasilkan dapat berupa grafik atau gambar. Grafik yang dihasilkan ini adalah grafik yang berbasis vektor sehingga animasi yang ditampilkan lebih cepat dan terlihat halus jika diakses melalui internet. Flash juga memiliki kemampuan untuk mengimpor file suara, video maupun file gambar dari aplikasi lain hasil dapat dipublikasikan ke dalam bentuk file.apk sehingga dapat dijalankan pada aplikasi Android. Adapun gambar yang digunakan pada aplikasi media pembelajaran perkalian dan pembagian ini seperti pada Tabel 5.

Tabel 5. Gambar Pada Aplikasi

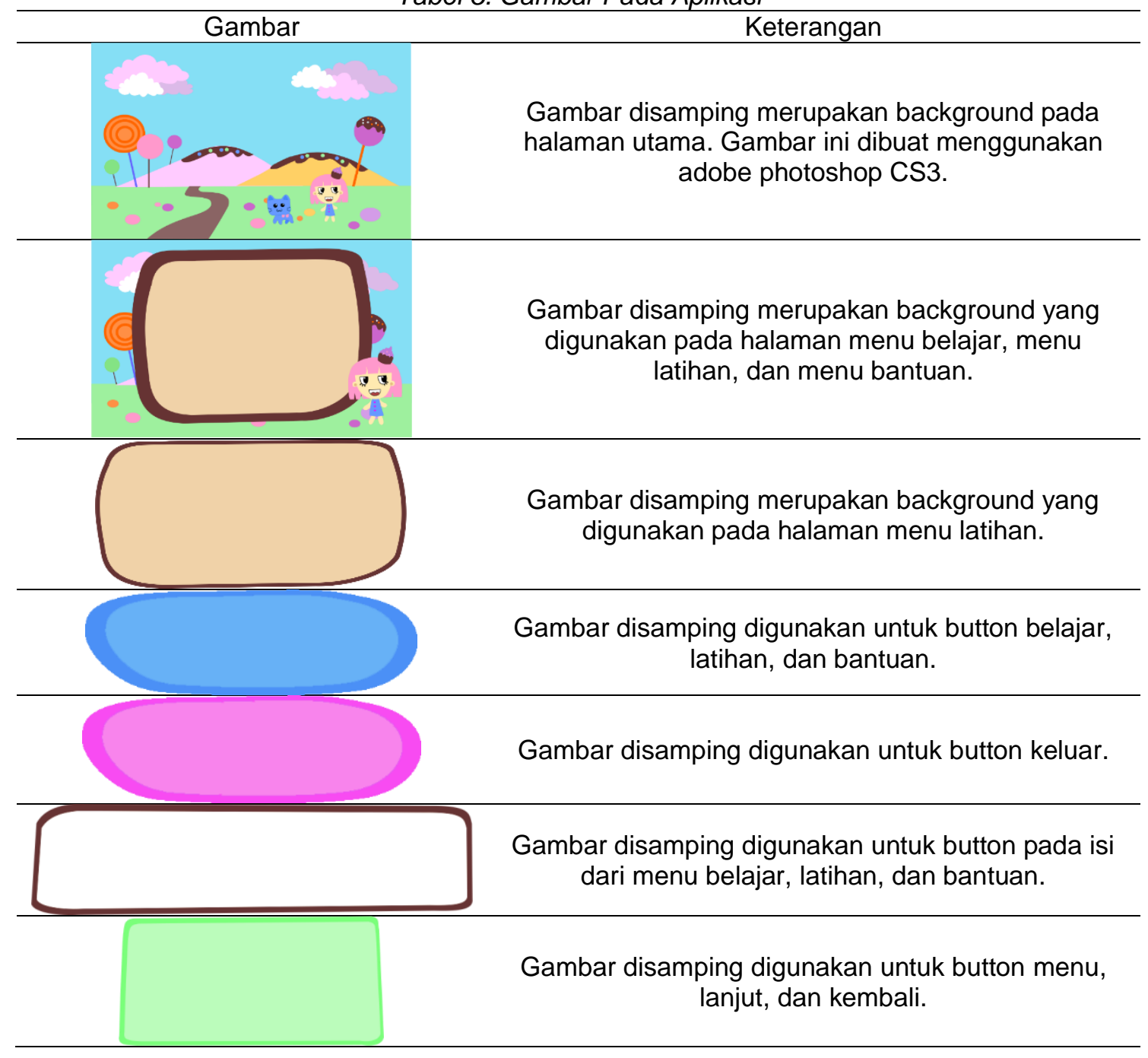

\subsubsection{Pembuatan (Assembly)}

Tahapan ini merupakan langkah untuk pembuatan aplikasi berdasarkan storyboard yang telah dibuat sebelumnya dari tahap desain, aplikasi media pembelajaran operasi hitung perkalian dan pembagian berbasis android.

Pada bagian ini akan menjelaskan antarmuka (interface) pada aplikasi media pembelajaran operasi hitung perkalian dan pembagian yang telah dibuat ini. 
a. Halaman Utama

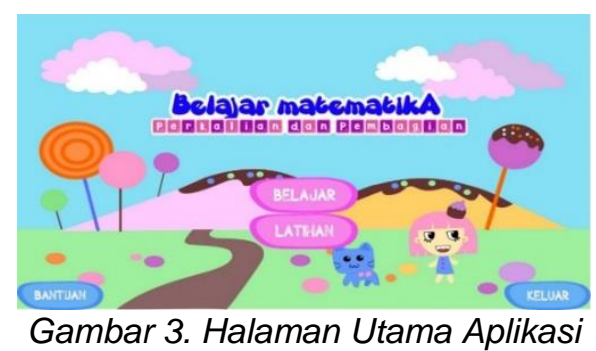

Pada Gambar 3 merupakan halaman utama aplikasi media pembelajaran metematika, dimana terdapat 4 button yang dapat dipilih untuk lanjut ke tahap selanjutnya. Button belajar untuk ke halaman belajar, button latihan untuk ke halaman latihan, button bantuan untuk ke halaman bantuan, dan button keluar untuk keluar dari aplikasi ini.

b. Halaman Pilihan Belajar

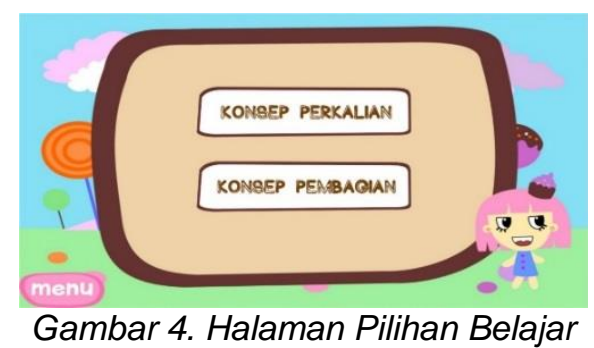

Pada Gambar 4 merupakan halaman ketika pengguna (user) memilih button belajar, terdapat 2 pilihan untuk ke tahap konsep perkalian yang berisi tutorial untuk belajar menyelesaikan soal perkalian, dan konsep pembagian yang berisi tutorial untuk belajar menyelesaikan soal pembagian.

c. Halaman Konsep Perkalian

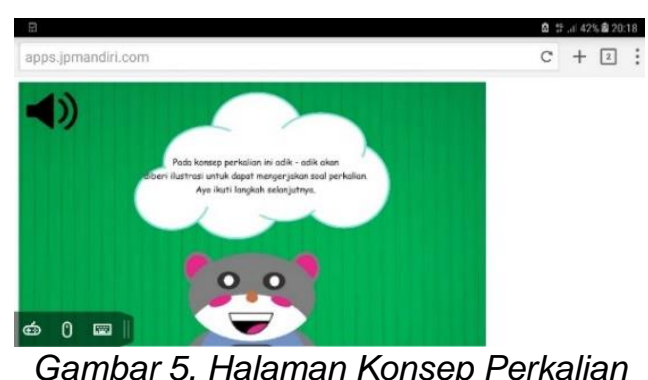

Pada Gambar 5 menjelaskan penerapan kondisi halaman yang akan tampil pada fitur konsep perkalian, halaman tersebut merupakan hasil load ke browser untuk dapat membuka animasi flash untuk materi berhitung perkalian yang telah tersedia.

d. Halaman Pilihan Latihan

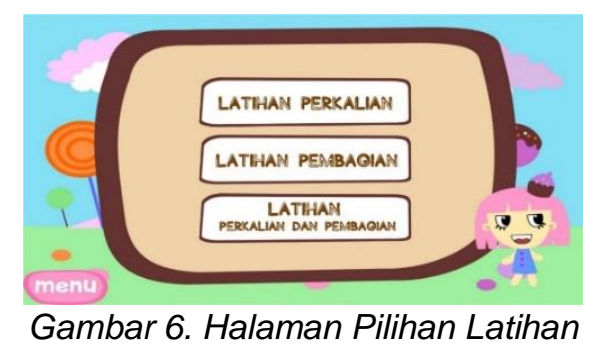

REPOSITOR, Vol. 2, No. 2, Februari 2020: 225-238 
Pada Gambar 6 merupakan halaman untuk memilih latihan evaluasi yang ingin pengguna (user) kerjakan, pada halaman tersebut berisi latihan untuk pembelajaran perkalian, latihan untuk pembelajaran pembagian, dan terdapat latihan campuran yang berisi pembelajaran perkalian dan pembagian.

e. Halaman Latihan Perkalian

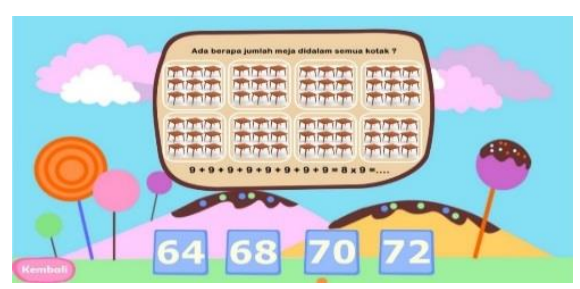

Gambar 7. Halaman Latihan Perkalian

Pada Gambar 7 merupakan halaman latihan untuk pembelajaran perkalian, dalam sekali latihan evaluasi perkalian berbentuk pilihan ganda yang telah disediakan dibawah soal merupakan salah satu jawaban yang benar. Pada setiap kali evaluasi akan tampil 10 soal pertanyaan tentang perkalian, ketika pengguna telah selesai menjawab 10 soal perkalian maka akan tampil skor yang berisi jumlah jawaban yang benar dari setiap satu kali evaluasi yang dimainkan oleh penguna. Pada halaman skor akan ada tombol kembali untuk menampilkan halaman pilihan latihan.

f. Halaman Latihan Pembagian

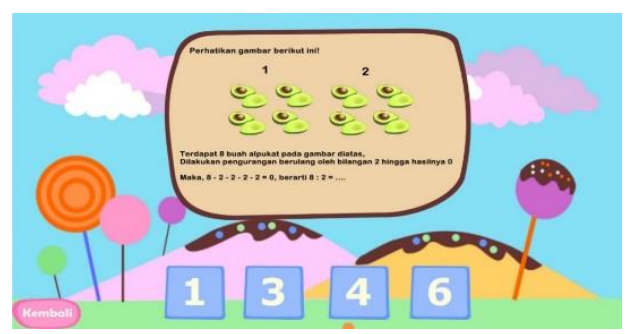

Gambar 8. Halaman Latihan Pembagian

Pada Gambar 8 merupakan halaman latihan untuk pembelajaran pembagian, dalam sekali latihan evaluasi pembagian berbentuk pilihan ganda yang telah disediakan dibawah soal merupakan salah satu jawaban yang benar. Pada setiap kali evaluasi akan tampil 10 soal pertanyaan tentang pembagian, ketika pengguna telah selesai menjawab 10 soal pembagian maka akan tampil skor yang berisi jumlah jawaban yang benar dari setiap satu kali evaluasi yang dimainkan oleh penguna. Pada halaman skor akan ada tombol kembali untuk menampilkan halaman pilihan latihan.

g. Halaman Skor (Score)

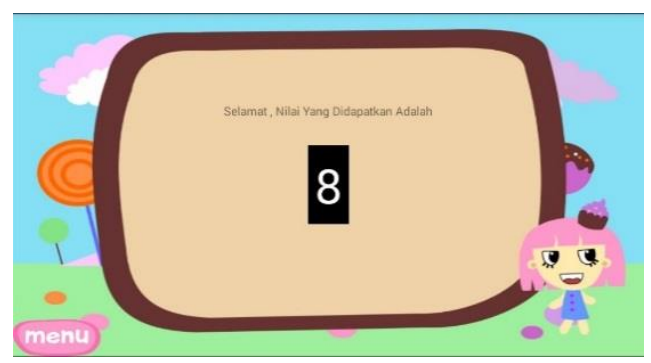

Gambar 9. Halaman Skor (Score)

Pada Gambar 9 merupakan halaman skor ketika pengguna telah selesai menjawab 10 soal dalam kurang dari waktu selama 1 menit, maka akan tampil skor atau nilai dari soal yang telah mereka jawab. 
h. Halaman Pilihan Bantuan

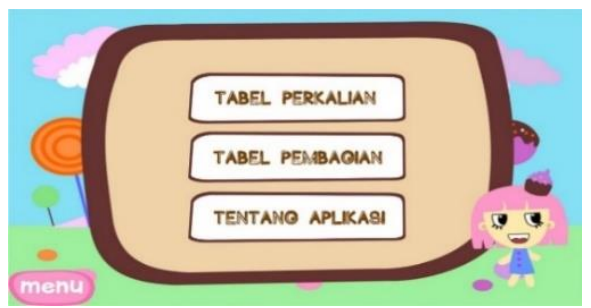

Gambar 10. Halaman Pilihan Bantuan

Pada Gambar 10 merupakan pilihan untuk menu bantuan, pada halaman ini berisi pilihan untuk melihat tabel perkalian, tabel pembagian, dan tentang aplikasi yang berisi tentang penjelasan penggunaan aplikasi media pembelajaran ini.

i. Halaman Tabel Perkalian

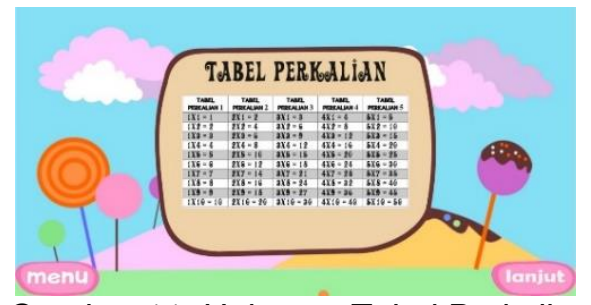

Gambar 11. Halaman Tabel Perkalian

Pada Gambar 11 merupakan halaman tabel perkalian ini berisi tabel perkalian 1 hingga 5 , button lanjut untuk melanjutkan tampilan perkalian 6 hingga 10. Dan button menu untuk kembali pada halaman utama.

j. Halaman Tabel Pembagian

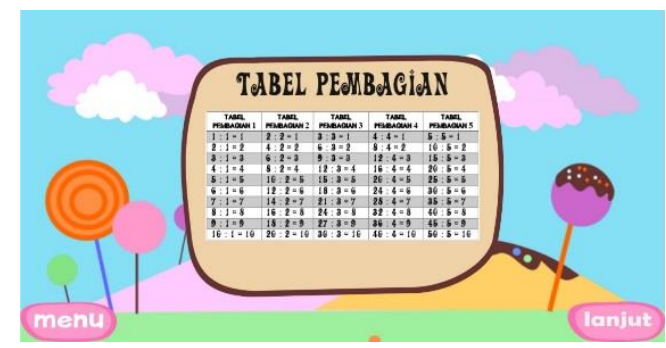

Gambar 12. Halaman Tabel Pembagian

Pada Gambar 12 ini merupakan halaman tabel pembagian ini berisi tabel pembagian 1 hingga 5, button lanjut untuk melanjutkan tampilan pembagian 6 hingga 10. Dan button menu untuk kembali pada halaman utama.

k. Halaman Tentang Aplikasi

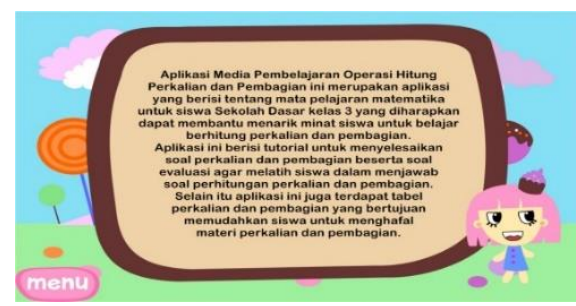

Gambar 13. Halaman Tentang Aplikasi

REPOSITOR, Vol. 2, No. 2, Februari 2020: 225-238 
Pada Gambar 13 ini merupakan halaman tentang aplikasi yang berisi tentang penjelasan penggunaan aplikasi media pembelajaran matematika perkalian dan pembagian ini.

\subsubsection{Pengujian (Testing)}

Tahap ini merupakan proses untuk menemukan kesalahan program sebelum digunakan oleh pengguna (user). Salah satu pengujian perangkat lunak adalah black-box testing yang merupakan pengujian yang fokus dalam spesifikasi fungsional dari perangkat lunak, penguji dapat mendefinisikan kumpulan kondisi input dan melakukan tester pada spesifikasi fungsional program, serta selain itu juga melakukan tes kegunaan untuk mengevaluasi aplikasi yang telah dibuat dengan menggunakan metode System Usability Testing (SUS) [10] .

\subsubsection{Distribusi (Distribution)}

Merupakan tahap untuk melakukan evaluasi aplikasi yang telah dibangun supaya menjadi lebih baik. Hasil dari evaluasi tersebut dapat menjadi masukan untuk pembuatan aplikasi selanjutnya. Tujuan pendistribusian adalah untuk menyebarluaskan aplikasi media pembelajaran ini, sehingga banyak yang bisa menggunakan aplikasi ini terutama pada kalangan anak-anak. Hasil dari program aplikasi media pembelajaran akan diekspor menjadi file berekstensi .apk yang bisa digunakan pada smartphone (android).

\section{Hasil Penelitian dan Pembahasan}

Pada tahap ini akan menjelaskan dan pengujian terhadap aplikasi media pembelajaran operasi hitung perkalian dan pembagian yang telah dibuat, berikut penjelasannya.

\subsubsection{Skenario Pengujian}

Pengujian pada aplikasi ini dilakukan dengan menggunakan pengujian fungsional yang menggunakan metode black-box testing dimana pengujian ini lebih menekankan spesifikasi fungsional dari aplikasi yang telah dibuat [8]. Selain black-box testing pada penelitian ini juga melakukan pengujian tes kegunaan menggunakan metode System Usability Scale (SUS) yang merupakan skala uji terhadap kegunaan aplikasi yang telah dibuat dari skala likert [9].Jumlah pertanyaan yang diajukan sebanyak 10 soal dimana mencakup beberapa aspek dari sistem usability seperti : training (pelatihan), support (dukungan), dan kompleksitas dimana memiliki tingkat validitas tinggi untuk mengukur sistem usability.

Pengujian pertama jumlah responden sebanyak 39 orang yang duduk dikelas 3 sekolah dasar. Siswa dijelaskan terlebih dahulu tentang jalan nya aplikasi, kemudian mereka mencoba aplikasi yang telah dibuat secara satu persatu maju kedepan kelas. Setelah mereka selesai mencoba aplikasi, siswa diberikan pernyataan-pernyataan sesuai dengan metode system usability scale (SUS). Pengujian ini menggunakan emotion card untuk mengukur tingkat respon pengguna.

Pengujian kedua dilakukan dengan jumlah responden sebanyak 34 siswa kelas 3 sekolah dasar. Siswa terlebih dahulu menjawab soal pertanyaan materi perkalian dan pembagian dibuku tulis mereka, kemudian setelah selesai mereka kembali menggunakan aplikasi untuk menjawab soal pada fitur latihan. Setelah itu mereka diminta untuk menjawab soal-soal kuisioner untuk mengukur tingkat kesenangan mereka apakah lebih menyukai menggunakan buku tulis atau menggunakan aplikasi ini untuk mengerjakan soal-soal tentang perkalian dan pembagian.

\subsubsection{Hasil Pengujian Black-box Testing}

Pengujian aplikasi media pembelajaran operasi hitung perkalian dan pembagian berbasis android dilakukan dengan menggunakan metode black-box. Pengujian ditekankan pada fungsionalitas dari aplikasi yang telah dibuat. Tahap ini merupakan serangkaian pengujian fungsi dan tombol yang digunakan pada aplikasi.

Hasil pengujian aplikasi dengan menggunakan metode black-box pada Tabel 6 menunjukkan bahwa permainan sudah berjalan berdasarkan spesifikasi kebutuhan dan skenario aplikasi. Hal yang telah ditampilkan pada seluruh tabel pengujian menunjukan hasil uji "Berhasil" untuk setiap tombol dan fungsi dari aplikasi. Hal ini menunjukaaan bahwa secara fungsional aplikasi ini sudah mengasilkan keluaran (output) yang diharapkan. 


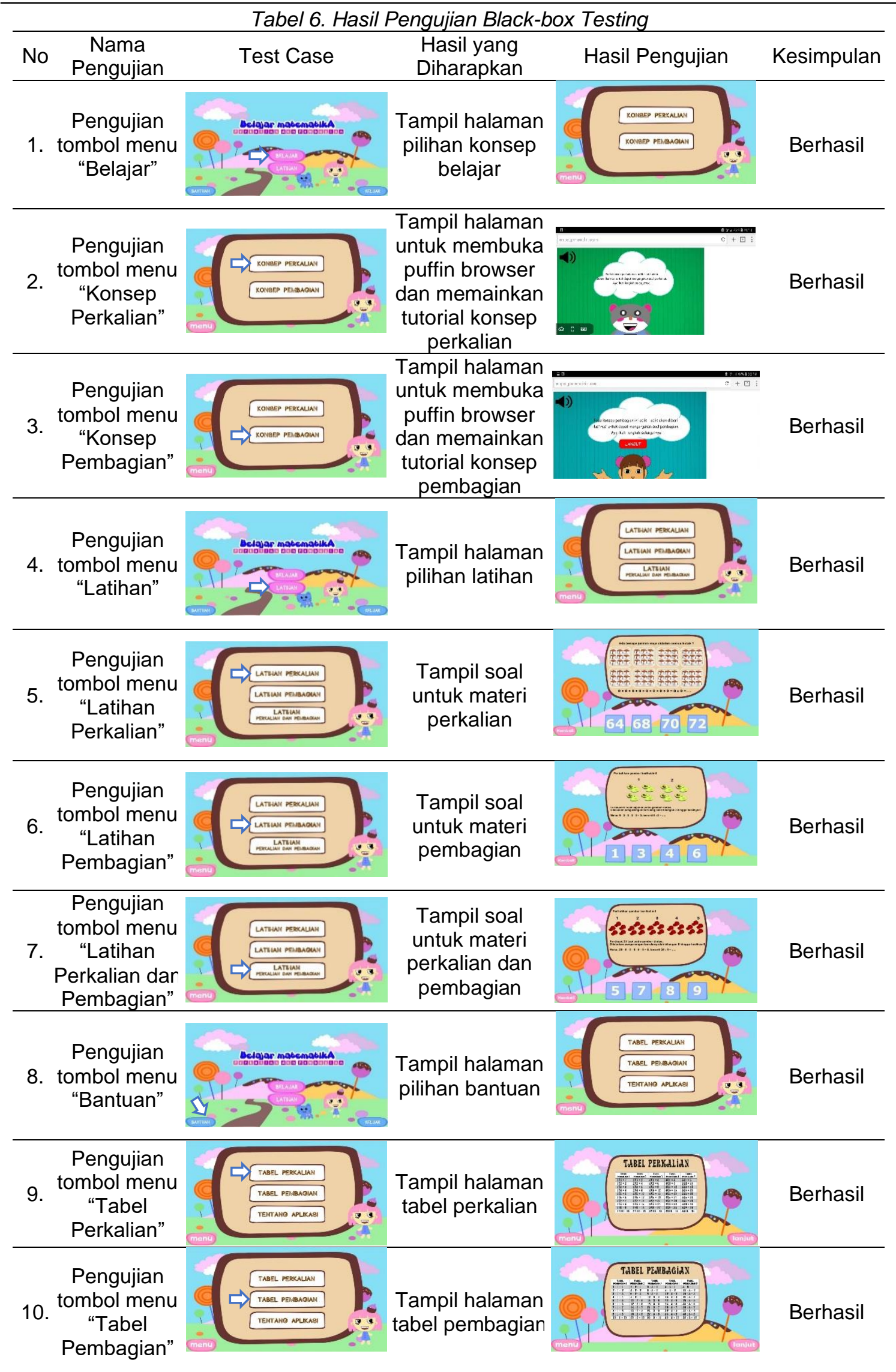

REPOSITOR, Vol. 2, No. 2, Februari 2020: 225-238 


Pengujian
11. $\begin{aligned} & \text { Tampol menu } \\ & \text { "Tentang } \\ & \text { Aplikasi" }\end{aligned}$ tentang aplikasi

\subsubsection{Hasil Pengujian System Usability Scale (SUS)}

Pengujian tes kegunaan dilakukan dengan menggunakan metode System Usability Scale (SUS) yang berbentuk kuisioner, hal ini digunakan sebagai cara untuk mendapatkan hasil tingkat kesesuaian dari aplikasi yang telah dibuat. Kuisioner ini berisi 10 pernyataan dimana mencakup beberapa aspek dari sistem usability seperti: training (pelatihan), support (dukungan), dan kompleksitas dimana memiliki tingkat validitas tinggi untuk mengukur sistem usability. Jumlah responden yang digunakan sebagai sampel berjumlah 39 siswa sekolah dasar kelas 3 . Skala yang digunakan sebanyak 5 ekspresi, emotion ketawa mewakili skala sangat setuju, emotion senyum mewakili skala setuju, emotion datar mewakili skala cukup, emotion sedih mewakili skala tidak setuju, emotion kecewa mewakili skala sangat tidak setuju. Pemilihan subjek responden sudah memenuhi kriteria sampel. Untuk rancangan skala yang digunakan akan dijelaskan pada Tabel 7.

Tabel 7. Skala Likert

\begin{tabular}{ccc}
\hline Skala & Keterangan & Bobot Nilai \\
\hline SS & Sangat Setuju & 5 \\
S & Setuju & 4 \\
C & Cukup & 3 \\
TD & Tidak Setuju & 2 \\
STD & Sangat Tidak Setuju & 1 \\
\hline
\end{tabular}

Tabel 8. Contoh Salah Satu Hasil Kuisioner Dari Responden

\begin{tabular}{|c|c|c|c|c|c|c|}
\hline \multirow[b]{2}{*}{ No } & \multirow[b]{2}{*}{ Pernyataan } & \multicolumn{5}{|c|}{ Pilihan Jawaban } \\
\hline & & $\begin{array}{l}\text { Sangat } \\
\text { Setuju } \\
\text { (Ketawa) }\end{array}$ & $\begin{array}{c}\text { Setuju } \\
\text { (Senyum) }\end{array}$ & $\begin{array}{l}\text { Cukup } \\
\text { (Datar) }\end{array}$ & $\begin{array}{l}\text { Tidak } \\
\text { Setuju } \\
\text { (Sedih) }\end{array}$ & $\begin{array}{c}\text { Sangat } \\
\text { Tidak Setuju } \\
\text { (Cemberut) }\end{array}$ \\
\hline 1 & $\begin{array}{l}\text { Adik-adik berpikir } \\
\text { untuk lebih sering } \\
\text { menggunakan } \\
\text { aplikasi belajar } \\
\text { perkalian dan } \\
\text { pembagian ini. }\end{array}$ & $\sqrt{ }$ & & & & \\
\hline 2 & $\begin{array}{c}\text { Adik-adik } \\
\text { menemukan bahwa } \\
\text { tampilan aplikasi } \\
\text { nya sederhana. }\end{array}$ & & & & & $\sqrt{ }$ \\
\hline 3 & $\begin{array}{l}\text { Adik-adik bisa } \\
\text { menggunakan } \\
\text { aplikasi media } \\
\text { pembelajaran ini. }\end{array}$ & $\sqrt{ }$ & & & & \\
\hline 4 & $\begin{array}{l}\text { Adik-adik berpikir } \\
\text { membutuhkan } \\
\text { pendamping untuk } \\
\text { bisa menggunakan } \\
\text { aplikasi ini. }\end{array}$ & & & & $\sqrt{ }$ & \\
\hline 5 & $\begin{array}{c}\text { Adik-adik } \\
\text { menemukan setiap } \\
\text { fungsi terintegrasi } \\
\text { dengan baik. }\end{array}$ & & $\sqrt{ }$ & & & \\
\hline 6 & $\begin{array}{l}\text { Adik-adik berpikir } \\
\text { ada banyak yang }\end{array}$ & & & & $\sqrt{ }$ & \\
\hline
\end{tabular}




\begin{tabular}{|c|c|c|c|c|}
\hline & $\begin{array}{c}\text { tidak sesuai pada } \\
\text { aplikasi ini }\end{array}$ & & & \\
\hline 7 & $\begin{array}{c}\text { Adik-adik berpikir } \\
\text { bisa mempelajari } \\
\text { cara menggunakan } \\
\text { aplikasi ini dengan } \\
\text { cepat. }\end{array}$ & $\sqrt{ }$ & & \\
\hline 8 & $\begin{array}{c}\text { Adik-adik berpikir } \\
\text { aplikasi ini sulit untuk } \\
\text { digunakan. }\end{array}$ & & & $\sqrt{ }$ \\
\hline 9 & $\begin{array}{l}\text { Adik-adik merasa } \\
\text { yakin untuk bisa } \\
\text { menggunakan } \\
\text { aplikasi ini. }\end{array}$ & & $\sqrt{ }$ & \\
\hline 10 & $\begin{array}{l}\text { Adik-adik perlu } \\
\text { belajar banyak hal } \\
\text { sebelum bisa } \\
\text { menggunakan } \\
\text { aplikasi ini. }\end{array}$ & $\sqrt{ }$ & & \\
\hline
\end{tabular}

Dari Tabel 8 merupakan hasil dari salah responden yaitu siswa sekolah dasar kelas 3 , berikut ini merupakan penjelasan tentang perhitungan kuisioner:

a. Pernyataan nomor 1 dipilih posisi sangat setuju dengan skala yaitu 5 maka untuk skor nya adalah 5 dikurangi 1, hasilnya 4. (posisi skala dipilih dikurangi 1)

b. Pernyataan nomor 2 dipilih posisi sangat tidak setuju dengan skala yaitu 1 maka untuk skor nya adalah 5 dikurangi 1 , hasilnya 4 . (5 dikurangi posisi skala yang dipilih)

c. Pernyataan nomor 3 dipilih posisi sangat setuju dengan skala yaitu 5 maka untuk skor nya adalah 5 dikurangi 1, hasilnya 4. (posisi skala dipilih dikurangi 1)

d. Pernyataan nomor 4 dipilih posisi tidak setuju dengan skala yaitu 2 maka untuk skor nya adalah 4 dikurangi 1, hasilnya 3 . (5 dikurangi posisi skala yang dipilih)

e. Pernyataan nomor 5 dipilih posisi setuju dengan skala yaitu 4 maka untuk skor nya adalah 4 dikurangi 1 , hasilnya 3 . (posisi skala dipilih dikurangi 1)

f. Pernyataan nomor 6 dipilih posisi tidak setuju dengan skala yaitu 2 maka untuk skor nya adalah 4 dikurangi 1 , hasilnya 3 . (5 dikurangi posisi skala yang dipilih)

g. Pernyataan nomor 7 dipilih posisi sangat setuju dengan skala yaitu 5 maka untuk skor nya adalah 5 dikurangi 1, hasilnya 4. (posisi skala dipilih dikurangi 1)

h. Pernyataan nomor 8 dipilih posisi sangat tidak setuju dengan skala yaitu 1 maka untuk skor nya adalah 5 dikurangi 1 , hasilnya 4 . (5 dikurangi posisi skala yang dipilih)

i. Pernyataan nomor 9 dipilih posisi cukup dengan skala yaitu 3 maka untuk skor nya adalah 3 dikurangi 1, hasilnya 2. (posisi skala dipilih dikurangi 1)

j. Pernyataan nomor 10 dipilih posisi sangat setuju dengan skala yaitu 5 maka untuk skor nya adalah 5 dikurangi 5 , hasilnya 0 . (5 dikurangi posisi skala yang dipilih)

Setelah masing-masing pernyataan dihitung skornya kemudian dijumlahkan dengan total hasil 31 selanjutnya dikalikan 2,5 untuk mendapatkan nilai System Usability Scale (SUS) yaitu 77,5 .

Dari 39 responden yang melakukan tes kegunaan dengan metode System Usability Scale (SUS), maka didapatkan rata-rata nilai skor SUS yaitu :

Nilai rata-rata $=\sum_{i=1}^{n} \frac{2942,5}{39}=75,449$

Keterangan: $X_{i}=$ Nilai skor semua responden

$\mathrm{N}=$ Jumlah Responden

Perhitungan system usability scale (SUS) didapat dengan cara mencari nilai rata-rata dari seluruh responden. Hal ini yang menjadi informasi layak atau tidaknya aplikasi yang dibangun. Nilai yang didapat untuk aplikasi ini yaitu 75, 449 sehingga dapat dikatakan bahwa aplikasi ini telah berjalan dengan baik.

Pada Tabel 9 didapatkan dari jawaban responden 34 siswa bahwa aplikasi ini dapat membantu mereka untuk belajar perkalian dan pembagian. Dari hasil jawaban kuisioner siswa lebih tertarik memilih untuk menggunakan aplikasi, karena aplikasi ini dapat mereka gunakan

REPOSITOR, Vol. 2, No. 2, Februari 2020: 225-238 
ketika belajar dirumah dan dibandingkan dengan belajar dengan menggunakan buku. Karena dengan aplikasi mereka bisa menggunakan dimanapun dan kapanpun.

Tabel 9. Hasil Kuisioner Pengujian II

\begin{tabular}{|c|c|c|c|c|c|c|}
\hline \multirow[b]{2}{*}{ No } & \multirow[b]{2}{*}{ Pernyataan } & \multicolumn{5}{|c|}{ Pilihan Jawaban } \\
\hline & & $\begin{array}{l}\text { Sangat } \\
\text { Setuju } \\
\text { (Ketawa) }\end{array}$ & $\begin{array}{c}\text { Setuju } \\
\text { (Senyum) }\end{array}$ & $\begin{array}{l}\text { Cukup } \\
\text { (Datar) }\end{array}$ & $\begin{array}{l}\text { Tidak } \\
\text { Setuju } \\
\text { (Sedih) }\end{array}$ & $\begin{array}{c}\text { Sangat } \\
\text { Tidak Setuju } \\
\text { (Cemberut) }\end{array}$ \\
\hline 1 & $\begin{array}{c}\text { Apakah adik-adik } \\
\text { senang ketika } \\
\text { menggunakan } \\
\text { aplikasi belajar } \\
\text { perkalian dan } \\
\text { pembagian ini? } \\
\end{array}$ & 16 & 8 & 7 & 2 & 1 \\
\hline 2 & $\begin{array}{c}\text { Apakah aplikasi ini } \\
\text { memiliki tampilan } \\
\text { gambar dan animasi } \\
\text { yang bagus? }\end{array}$ & 3 & 20 & 9 & 2 & 0 \\
\hline 3 & $\begin{array}{l}\text { Apakah teks atau } \\
\text { tulisan aplikasi ini } \\
\text { mudah untuk dibaca? }\end{array}$ & 7 & 18 & 9 & 0 & 0 \\
\hline 4 & $\begin{array}{c}\text { Apakah adik-adik } \\
\text { lebih suka belajar } \\
\text { perkalian pembagian } \\
\text { seperti belajar } \\
\text { dikelas dengan } \\
\text { menggunakan buku? }\end{array}$ & 2 & 9 & 12 & 8 & 3 \\
\hline
\end{tabular}

\section{Kesimpulan dan Saran}

4.1 Kesimpulan

Dari penelitian yang telah dilakukan terhadap pembuatan aplikasi media pembelajaran operasi hitung perkalian dan pembagian berbasis android, maka didapatkan beberapa kesimpulan, yaitu:

1. Aplikasi tersebut diuji dengan black-box dengan hasil telah sesuai dengan fungsi yang diharapkan. Sehingga ketika siswa menggunakan aplikasi tersebut tidak mengalami kendala fungsional.

2. Hasil pengujian dengan melakukan pengujian kuisioner tes kegunaan dengan metode System Usability Scale (SUS) kemudian dilakukan penghitungan nilai skor SUS sehingga mendapat nilai akhir 75,449.

3. Berdasarkan tabel 3.4 didapatkan hasil pengujian kuisioner kedua dimana hasil terbanyak yang dipilih siswa tentang pertanyaan nomor 1 yang menunjukkan kesenangan mereka terhadap aplikasi yaitu 16 orang memilih sangat setuju dari 34 siswa. Pertanyaan nomor 2 dan 3 menunjukkan tentang tampilan gambar dan tulisan yang ada pada aplikasi hasil terbanyak yang diperoleh yaitu 20 dan 18 orang memilih setuju. Dan pertanyaan nomor 4 yang menunjukkan kesukaan mereka untuk belajar dengan menggunakan buku tulis sehingga diperoleh hasil terbanyak yaitu 12 orang siswa memilih cukup dan hanya 2 orang yang memilih sangat setuju. Sehingga dapat disimpulkan bahwa siswa lebih senang menggunakan aplikasi dibandingkan buku tulis untuk belajar berhitung perkalian dan pembagian.

\subsection{Saran}

Saran yang dapat diberikan terhadap pengembangan aplikasi selanjutnya, yaitu:

1. Aplikasi dapat berjalan tidak hanya di platform android.

2. Materi untuk pengembangan lebih lanjut dapat ditambahkan materi perkalian dan pembagian lebih dari perkalian dan pembagian 10 agar bisa digunakan untuk siswa selain kelas 3 sekolah dasar.

3. Secara teknis aplikasi bisa dijalankan secara offline sehingga dapat memudahkan user untuk digunakan kapanpun dan dimanapun 


\section{Referensi}

[1] Delia Indrawati, Siti Partini Suardiman, (2013) "Pengembangan Media Travel Game Untuk Pembelajaran Perkalian dan Pembagian Bilangan Pecahan Matematika SD Kelas V," Jurnal Prima Edukasia, vol. 1.

[2] Fadli, (2014) "Pengembangan Model Pembelajaran Berbasis Web untuk Pelajaran Matematika," Jurnal Teknologi Pendidikan, vol. 16, no. 1, p. 13.

[3] Aris Rakhmadi, Umi Fadillah, Yasid Ardyanto, (2012) "Visiualisasi Pembelajaran Fungsi, Turunan, dan Integral Pada Mata Pelajaran Matematika SMA Kelas 2 Berbasis Macromedia Flash 8," KomunTI, vol. IV, no. 1, p. 53.

[4] E. Utami, (2013) "Penerapan Model Pembelajaran Teams Game Tournament (TGT) Melalui Pendekatan Matematika Realistik (PMR) Sebagai Upaya Peningkatan Hasil Belajar Pada Materi Pecahan Kelas IV A SDN-P Bantarjati 9 Bogor Tahun Ajaran 2012/2013," Pendidikan Dompet Dhuafa, vol. 3, no. 1, p. 48.

[5] Permana Andri, dkk (2016) "Pengaruh Virtual Laboratory Berbasis Flash Animation Terhadap Pemahaman Konsep dan Keterampilan Berpikir Kritis Peserta Didik Tema Optik Kelas VIII SMP" Universitas Negeri Semarang. ISSN 2252-6617

[6] A. Mulyawan, (2014) "Perancangan Media Interaktif Mata Pelajaran Matematika untuk Siswa SMP" Institut Teknologi Surabaya.

[7] Desnada Annisa, (2016) "Media Pembelajaran Interaktif Sakawira Kartika Di Kabupaten Tanah Laut Banjarmasin Berbasis Android", Universitas Muhammadiyah Malang.

[8] Syahrin, dkk (2015) "Perancangan dan Pengembangan Permainan "Super Sigi" Menggunakan Stencyl Sebagai Media Pengenalan Menyikat Gigi" Jurnal Teknologi dan Slstem Komputer.

[9] Fajariah Nur dan Triratnawati "Buku Cerdas Berhitung Matematika Untuk SD/MI kelas 3" Pusat Perbukuan Departemen Pendidikan Nasional, 2008

[10] Brooke, J. (1996). SUS : A quick and dirty usability scale. In P.W. Jordan, B.Thomas, B.A Weerdmeester\& I.L McClelland(Eds), Usabilty Evaluation in Industry (pp.189-194). London, UK : Taylor \& Francis. 